

\section{DISCLAIMER}

This report was prepared as an account of work sponsored by an agency of the United States Government. Neither the United States Government nor any agency Thereof, nor any of their employees, makes any warranty, express or implied, or assumes any legal liability or responsibility for the accuracy, completeness, or usefulness of any information, apparatus, product, or process disclosed, or represents that its use would not infringe privately owned rights. Reference herein to any specific commercial product, process, or service by trade name, trademark, manufacturer, or otherwise does not necessarily constitute or imply its endorsement, recommendation, or favoring by the United States Government or any agency thereof. The views and opinions of authors expressed herein do not necessarily state or reflect those of the United States Government or any agency thereof. 


\section{DISCLAIMER}

Portions of this document may be illegible in electronic image products. Images are produced from the best available original document. 


\section{Printed in the United States of America. Available from National Technical Information Service \\ U.S. Department of Commerce \\ 5285 Port Royal Road, Springfield, Virginia 22161 NTIS price codes-Printed Copy: A03 Microfiche A01}

This report was prepared as an account of work sponsored by an agency of the United States Government. Neither the United States Government nor any agency thereof, nor any of their employees, makes any warranty, express or implied, or assumes any legal liability or responsibility for the accuracy, completeness, or usefulness of any information, apparatus, product, or process disclosed, or represents that its use would not infringe privately owned rights. Reference herein to any specific commercial product, process, or service by trade name, trademark, manufacturer, or otherwise, does not necessarily constitute or imply its endorsement, recommendation, or favoring by the United States Government or any agency thereof. The views and opinions of authors expressed herein do not necessarily state or reflect those of the United States Government or any agency thereof. 
Contract No. W-7405-eng-26

\title{
THE EFFECT OF VIBRATIONS ON THE DENSITY OF LOOSE-FILL INSULATIONS
}

\author{
D. W. Yarbrough and J. H. Wright \\ Department of Chemical Engineering \\ Tennessee Technological University \\ Cookeville, TN 38501 \\ Subcontract 7715
}

\author{
Part of \\ The National Program for
}

Building Thermal Envelope Systems and Insulating Materials

\begin{abstract}
Research sponsored by the Office of Buildings and Community Systems, Buildings Division

U.S. Department of Energy
\end{abstract}

Date Published: May 1981

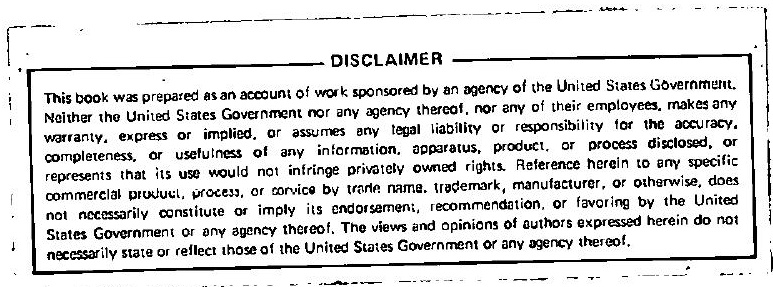

OAK RIDGE NATIONAL LABORATORY

Oak Ridge, Tennessee 37830 operated by UNION CARBIDE CORPORATION

for the

DEPARTMENT OF ENERGY 


\section{THIS PAGE}

\section{WAS INTENTIONALLY \\ LEFT BLANK}




\section{RELATED REPORTS}

1. DOE/CS-0059: The National Program Plan for Building Thermal Envelope Systems and Insulating Materials (January 1979).

2. LBL-8822: A New Measurement Strategy for In-Situ Testing of Wal1 ThermaT Performance (March 1979).

3. LBL-8925: Thermal Performance of Buildings and Building Envelope Systems: An Annotated Bibliography (March 1979).

4. ORNL/SUB-7556/I: Assessment of the Corrosiveness of Cellulosic Insulating MateriaTs (June 1979).

5. ORNL/SUB-7504/3: Recessed Light Fixture Test Facility (July 1979).

6. ORNL/SUB-7559/I: Problems Associated with the Use of UreaFormaldehyde Foam for Residential Insulation (September 1979).

7. ORNL/Sub-7551/I: Interim Progress Report on an Investigation of Energy Transport in Porous InsuTator Systems (October 1979).

8. ORNL/TM-6494: A Technique for Measuring the Apparent Conductivity of Flat Insulations (October 1979).

9. LBL-9821: Measurement of In-Situ Dynamic Thermal Performance of Building Envelopes Using Heat FTow Meter Arrays (December 1979):

10. ORNL/Sub-79/13660/I: Minnesota Retrofit Insulation In Situ Test Program Extension and Review (February 1980).

11. ORNL/TM-7266: An Experimental Study of Thermal Resistance Values (R-Values) of Low-Density Mineral-Fiber Building Insulation Batts Commercialty Available in 1977 (Aprif 1980).

12. NBS/BS Series 123: The Effect of Moisture on the 'Thermal Conductance of Roofing Systems (Aprit 1980).

13. ORNL/Sub-78/97726/I : A Field Study of Mo isture Damage in Walls Insulated Without a Vapor Barrier (May 1980).

14. ORNL/CON-46: An Appraisal of the MFactor and the Role of Building Thermal Mass in Energy Conservation (JuTy 1980).

15. ORNL/Sub-7686/I: Smoldering Combustion Hazards of Thermal Insulation Materials (July 1980).

16. NBSIR 80-2097: Precision Measurements on Fibrous Glass Insulation (JuTy 1980). 
17. NBSIR 80-2085: Fire Performance of Loose-Fill Cellulosic Insulation in Residential Occupancies (August 1980).

18. ORNL/Sub-7556/2: Corrosion Testing of Urea-Formaldehyde Foam Insulating Materials (September 1980).

19. NBSIR 80-2100: Thermal Resistance Measurements of a Built-Up Roof System (October 1980).

20. NBSIR 80-2129: Modeling for Determination of Temperatures of Electrical Cables Within Thermally Insulated Walls (October 1980).

21. ORNL/CON-61: An Experimental Plan for Investigating BuildingEarth Heat Transfer at the loint Institute for Heavy-Ion Research Buituing (hecember 1980).

22. ORNL/Sub-7715/1: Operating Temperatures for a Convectively Cooled Recessed Incandescent Light Fixture (December 1980).

23. ORNL/TM-7481: Analysis of Heat Transfer in Building Thermal Insulations (December 1980).

24. ORNL/tr-4679: Roofing Felt on Polystyrene (December 1980).

25. STP-718: Proceedings of ASTM/DOE Thermal Insulation Conference, Tampd, Florida, October 1978 (December 1980).

26. ORNL/Sub-7559/3: Problems Associated with the Use of UreaFormaldehyde Foam for Residential Insulation: Part III: Residential Studies in Colorado and Wisconsin (February 1981).

27. ORNL/Sub-7559/4: Problems Associated with the Use of UreaFormaldehyde Foam for Residential Insulation. Part IV: The Relevance of Materials Standards to Problems Associated with the Use of Urea-Formaldehyde Foam Insulation (February 1981.)

28. ORNL/Sub-7559/2: Problems Associated with the Use of UreaFormaldehyde Foam for Residential Insulation: Part II: The Effects of Temperature and Humidity on Free Formaldehyde, Extractable Formaldehyde, Formaldehyde Emission, and Physical Characteristics of the Fuaili (Februar'y 1981). 


\section{FOREWORD}

This is one of a series of reports to be published describing research, development, and demonstration activities in support of the National Program for Building Thermal Envelope Systems and Insulating Materials. The National Program involves several federal agencies and many other organizations in the public and private sectors who are addressing the national objective of decreasing energy wastes in the heating and cooling of buildings. Results described in this report are part of the National Program through delegation of management responsibilities for the DOE lead role to the Oak Ridge National Laboratory.

Ted S. Lundy

Program Manager

Building Thermal Envelope Systems and Insulating Materials

Oak Ridge National Laboratory

E. C. Freeman

Program Manager, Buildings Division

Office of Buildings and Community Systems

Department of Energy 
THIS PAGE

\section{WAS INTENTIONALLY LEFT BLANK}


The three major loose-fill insulation products marketed in this country have been subjected to a variety of vibrations and impacts in a laboratory setting to determine the magnitude of the resultant density increases. Repeated drops of $19 \mathrm{~mm}$ (.75 inch) and $152 \mathrm{~mm}$ ( 6 inch) produced density increases of up to $75 \%$ for fiberglass, $45 \%$ for rock wool and $27 \%$ for cellulosic materials. The three insulation products were also subjected to vibrations ranging from $0.1 \mathrm{~mm}$ (.004 inch) to $6.35 \mathrm{~mm}$ (.25 inch) to obtain ratios of final density over initial density. Under the test conditions studied it was observed that the lighter materials settled more percentagewise than the dense materials. 
The Effect of Vibrations on the Density

of Loose-Fịll Insulations

\section{Introduction}

The thermal resistance, $R$, of a layer of loose-fill insulating material depends on the thickness, L, and the apparent thermal conductivity; $k_{\text {app }}$, of the material. The R-value defined mathematically in Equation (1) is used by the insulation industry as an index of thermal performance.

$$
\begin{aligned}
& \mathrm{R}=\mathrm{L} / \mathrm{k}_{\text {app }} \\
& \mathrm{k}_{\text {app }}=(\mathrm{Q} / \mathrm{A}) /\left(\left(\mathrm{T}_{\mathrm{h}}-\mathrm{T}_{\mathrm{c}}\right) / \mathrm{L}\right) \\
& \mathrm{L} / \mathrm{L}_{\text {ref }}=\rho_{\mathrm{ref}} / \rho
\end{aligned}
$$

The thickness term in Equation. (1) is related to density, $\rho$, as shown In Equation (3). A reduction in thickness from the reference value, Lref, results in a corresponding increase in the density. The $k_{\text {app }}$ in Equation. (1) is commonly measured using devices such as the guarded hot plate or the heat flux meter. In both cases a heat flux, $Q / A$, and a leimperature gradient, $\left(T_{h}-T_{c}\right) / L$, are determined experimentally. The magnitude of $k$ app decreases with increased density in the range of densities normally encountered with loose-fill materials.

The thickness of a layer of insulation varies inversely with density while the relationship between $k_{\text {app }}$ and density is relatively weak. As a first approximation, therefore, $\mathrm{R}$-values vary direct1y with thickness or inversely with density. 
The specification of the density to be used in calculating the coverage obtainable from a given mass of loose-fill insulation (design density) is of primary interest to the consumer. An understanding of changes in the density with time is important for correct evaluation of long-term thermal performance and economic evaluation. The present study documents density increases in loose-fill insulations resulting from low frequency - low amplitude vibrations. Laboratory results will be given in terms of the density ratio, $\rho / \rho_{0}$, where $\rho_{0}$ is the blown density. The ratio will be referred to as the settling factor.

Vibrations in buildings occur as a result of activity within, the building. as well as external factors. This includes, for example, machines, processing equipment and occupant movements. A recent study by Medearis (1) of characteristic house dynamics showed that houses exhibit fundamental vibration frequencies in the range $5-15 \mathrm{~Hz}$. Medearis used seismometers in 63 residences to detect vibrations resulting from selected routine actions like the slamming of doors. A similar study completed by the National Association of Home Builders Research Foundation, Inc. (2), NAHBRF, used strain gauges to detect occupant induced vibrations. The NAHBRF study of a single structure detected frequencies in the $7-45 \mathrm{~Hz}$ range with amplitudes up to $0.13 \mathrm{~mm}(0.005$ inch). Smith and Scanlan (3) used an accelerometer to measure vibration frequencies and amplitudes in a single residence. A typical output of their analysis is shown in Figure 1. Low frequency-small amplitude vibrations were observed. In addition, however, the data in Figure 1 show high frequency, $1000-2000 \mathrm{~Hz}$, vibrations at low amplitudes. The results of all three vibration studies indicate the presence of low frequency-low amplitude disturbances in residential structures. The laboratory results in this paper are restricted to low frequency vibrations and impact tests. The effects of high frequency vibrations will be the subject of a future study. 
ORNL-DWG 81-9448

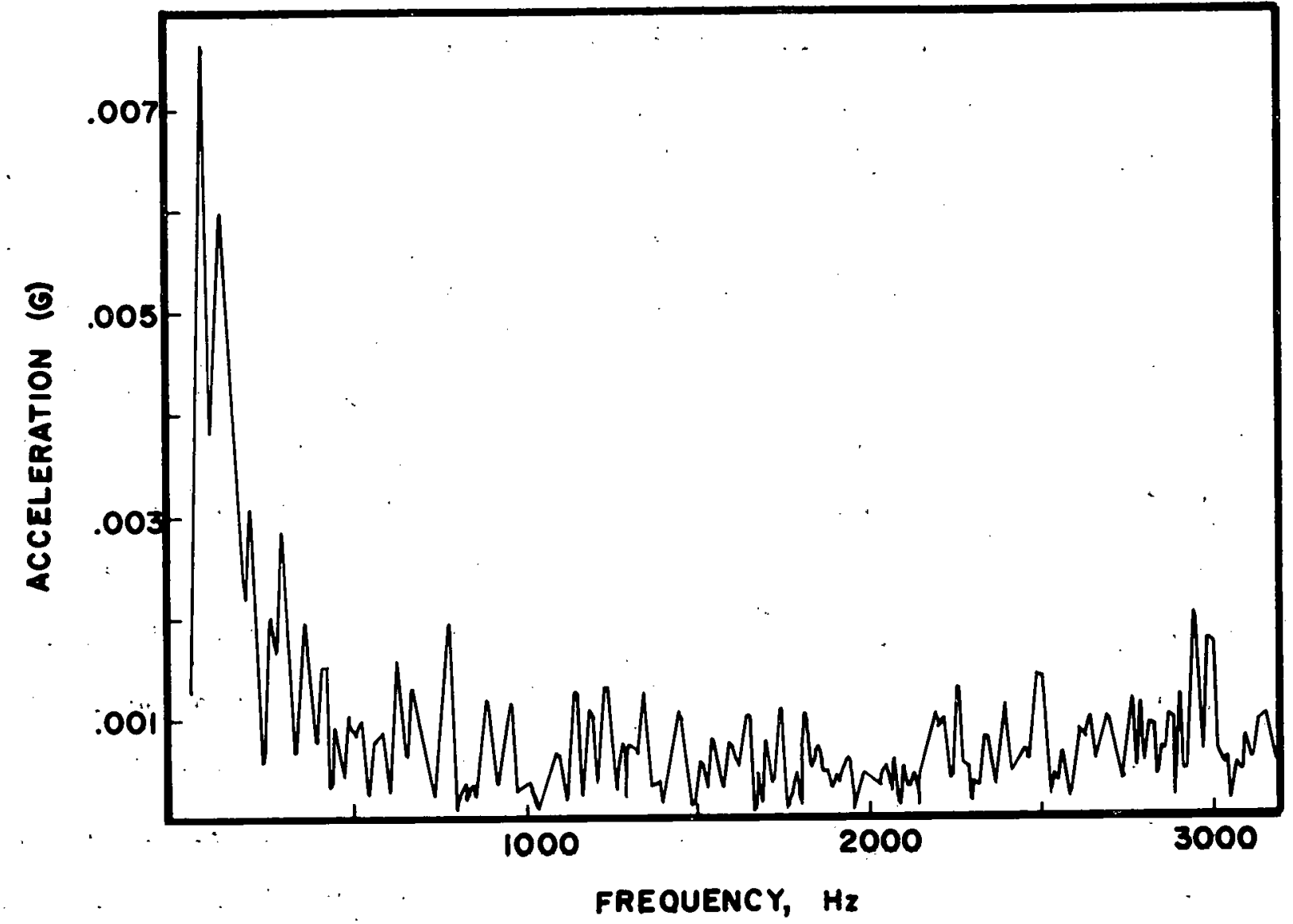

Figure 1. Accelerometer Record Resulting From Kitchen Work 
Experimental Procedure:

Specimens of blown loose-fill mineral fiber insulation were prepared using a truck mounted Insulation blowing machine manufactured by Unisul, Inc. (4) P1ywood boxes approximately $457 \mathrm{~mm}$ (18 inches) in length, $368 \mathrm{~mm}$ (14.5 inches) in width and $305 \mathrm{~mm}$ (12 inches) in depth were filied with loose-fill insulation using the mock attic shown in Figure 2. The insulation around the boxes after a blowing operation was removed manualiy and the insulation in the specimen box was leveled. The insulation-filled specimen boxes were then transportèd tó one of four cest stacions. Specimens of loose-fill cellulosic insulation were also prepared in the attic shown in Figure 2 using a hand-held Cadillac ${ }^{(5)}$ blower. In this case the insulation was moved to the suction side of the blower by gravity feed. The same vibration and impact tests were used for the loosefill cellulosic material that were used with the minerai fiber insulations. The vibration devices used in this study are pistured in Figures 3 and 4. Figure 3 shows a modified Syntron polishing machine ${ }^{(6)}$ that was used to subject specimens to $60 \mathrm{~Hz}$ vibrations with a vertical displacement component of $0.1 \mathrm{~mm}$ (.004 inches). The polisher was fitted with a plywood platform to facilitate the firm attachment of specimen boxes. Well defined vertical vibrations were obtained using the vibration testing machines shown in Figure 4. (4) The vibration testing inachine can be used to produce displacements up to $6.35 \mathrm{~mm}$ (.25 inch) at $10-60 \mathrm{~Hz}$.

A 19 (0.75 inch) drop test was conducted using the device pictured in Figure 5. This apparatus uses a notched cam to drop the specimen platform a measured distance. The shaft connected to the cam was equipped with an electronic counter to record the number of drops completed. The 


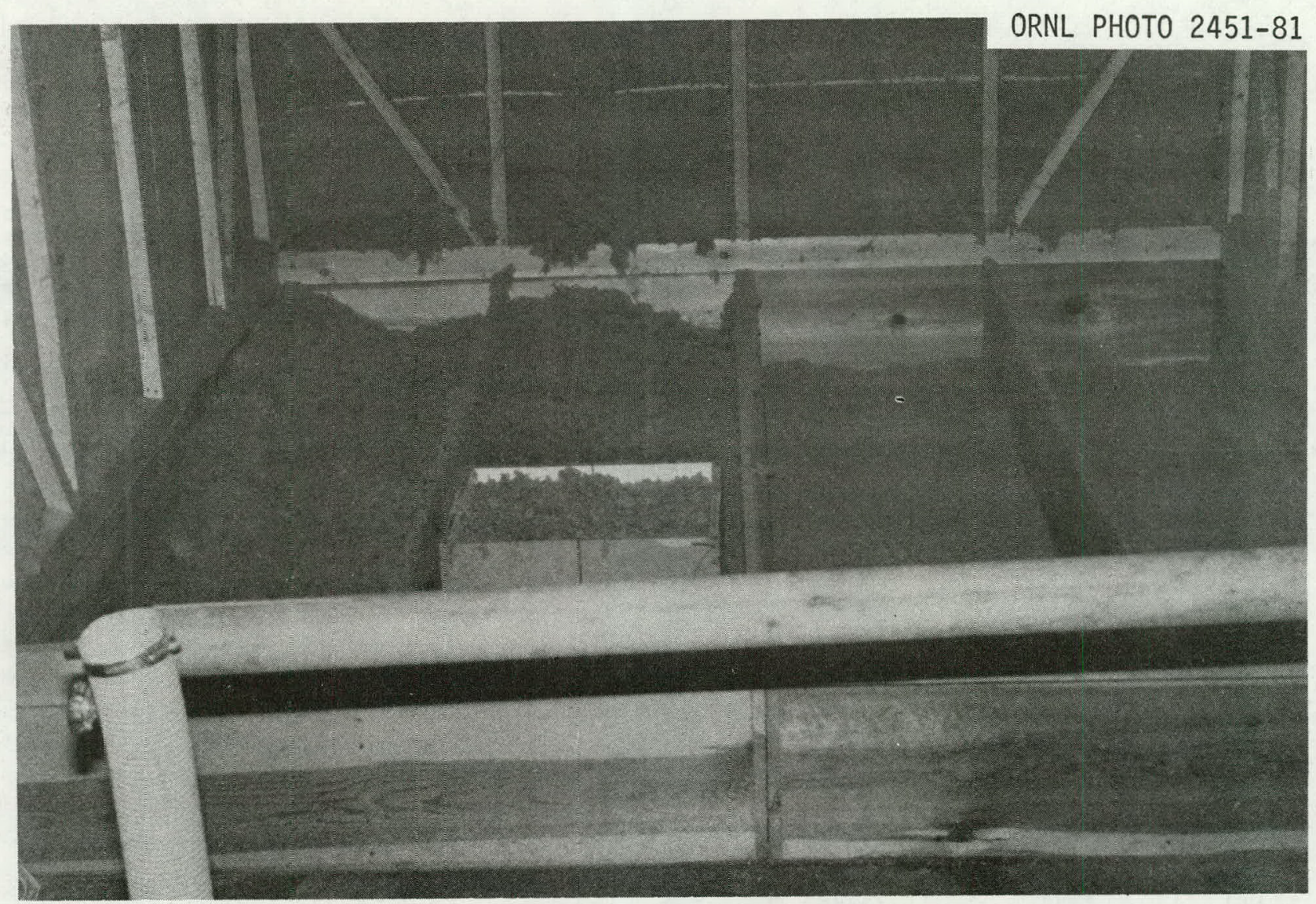

Figure 2.

Mock Attic For Specimen Preparation 

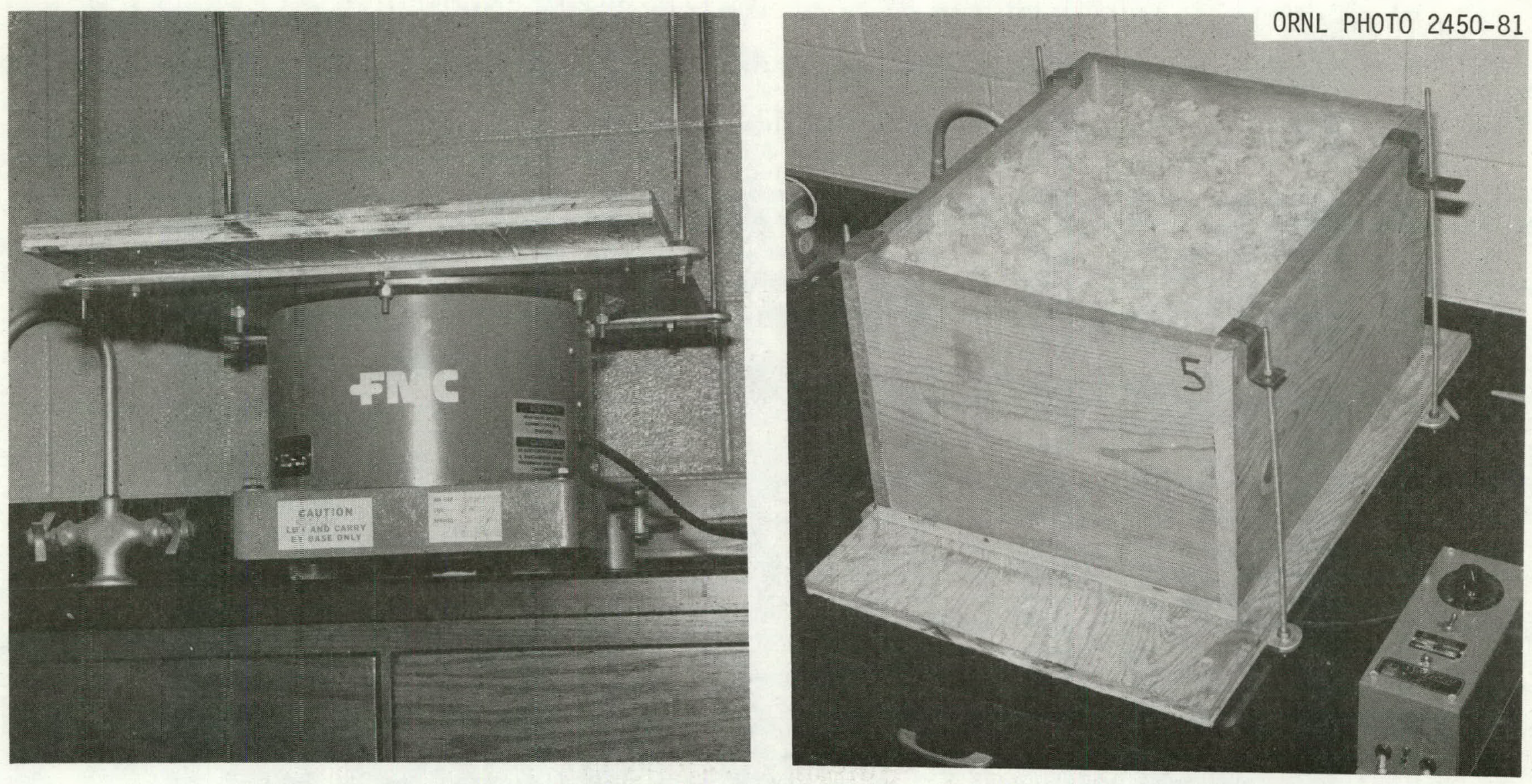

Figure 3

(a)

Modi=ied Polis:-irg Machine (a) Side View

(b)

Showing Spec-men Platform (b) Polisher

With Specimen Đox attached 


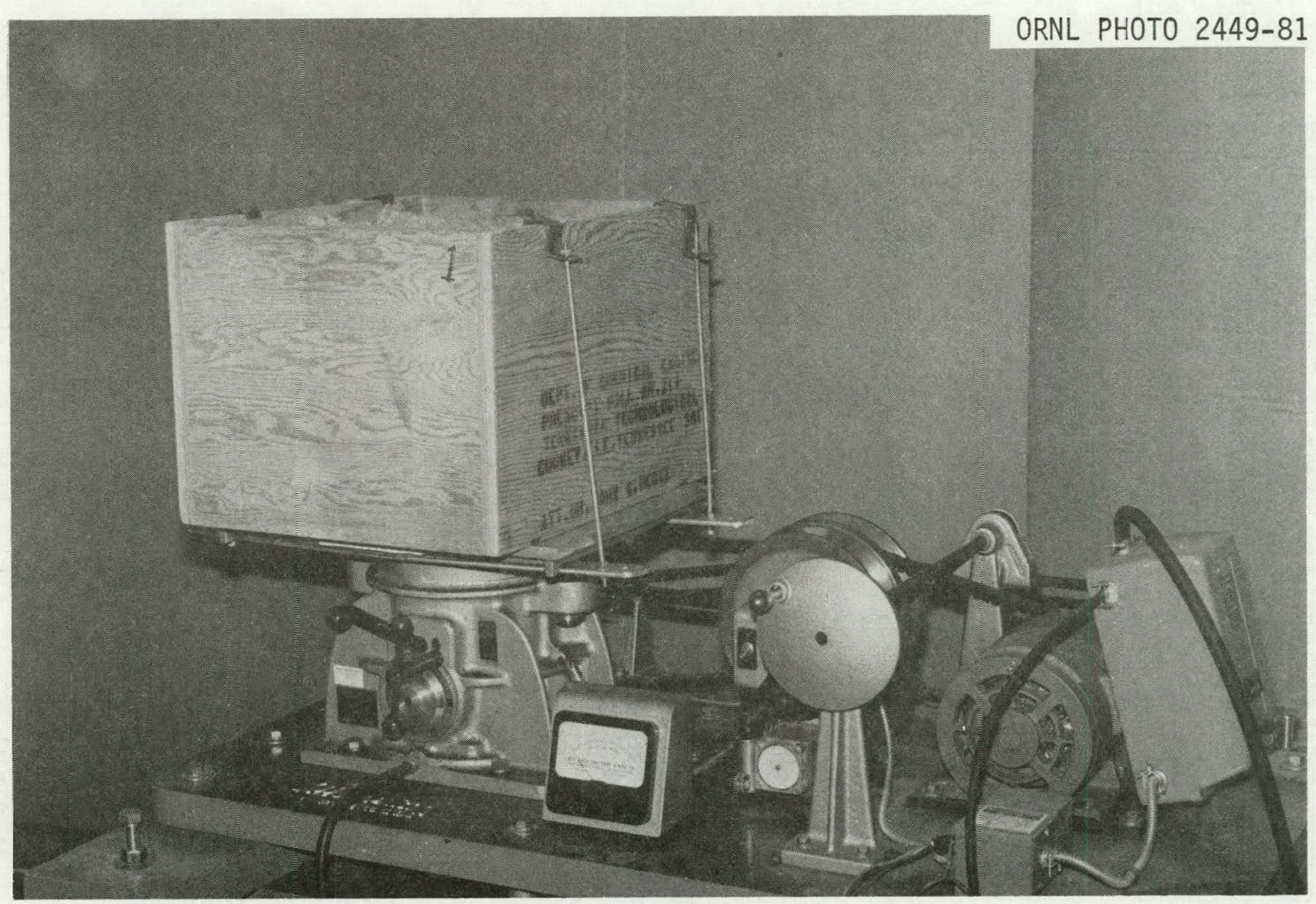

Figure 4.

Vibration Testing Machine With Specimen Box In Place 


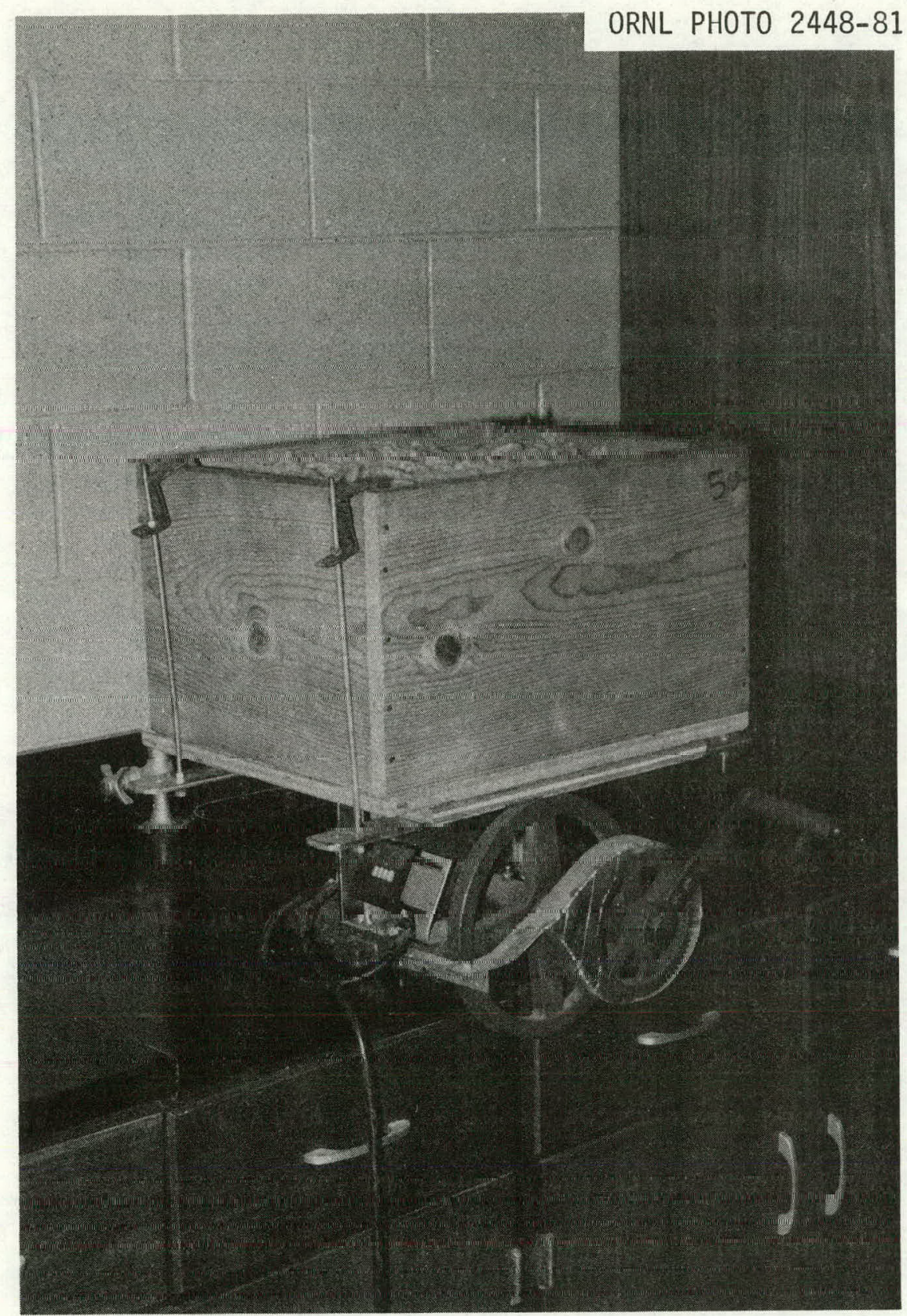

Figure 5. Apparatus For $19 \mathrm{~mm}$ Drop Test 
apparatus was operated manually.

A $152 \mathrm{~mm}\left(6.0\right.$ inch) drop test described by Bomberg and Shirtliffe ${ }^{(7)}$ was accomplished using a pulley system and a $152 \mathrm{~mm}$ spacer. This drop test was done using boxes $914 \mathrm{~mm}$ (36 inches) in length. In all cases a specimen was subjected to repeated drops with density determined as a function of the number of drops.

Insulation depths in the specimen boxes as blown and after specific vibration times or number of drops were measured to within $\pm 6 \mathrm{~mm}$ (.25 inch) using a tapered steel welding rod. Average depth was determined from five measurements. One measurement was made at the center of the specimen while the other four were centered in each of the four quadrants of the specimen surface. At the completion of a series of tests the mass of the insulation in the specimen box was determined to within $\pm 1.0 \mathrm{gram}$.

As a result of the procedures described above it was possible to determine the density of a loose-fill specimen after.measured amounts of vibration or number of drops. The density measurements are accurate to within $\pm 2 \%$. Results will be discussed in terms of a settling ratio which is the ratio of the density after vibration to the blown density, $\rho / \rho_{0}$.

\section{Discussion of Results}

Experimental values for $\rho / \rho_{0}$ as a function of vibration time on the modified polisher are shown in Figure 6 for loose-fill fiberglass, LFFG, and loose-fill rock wuul, LFRW, insulations. The results obtained at displacements of $0.1 \mathrm{~mm}(.004$ inches) and $60 \mathrm{~Hz}$ showed very small thickness changes and, consequently, the test was not used exhaustively. The settlement ratios for vibration times up to $10,000 \mathrm{~s}$ were 1.02 or less. One specimen of LFFG showed sufficient settlement, $\rho / \rho_{0}>1.04$, for the points to fall outside the band of experimental uncertainty. It was concluded that 
ORNL-DWG $81-9449$

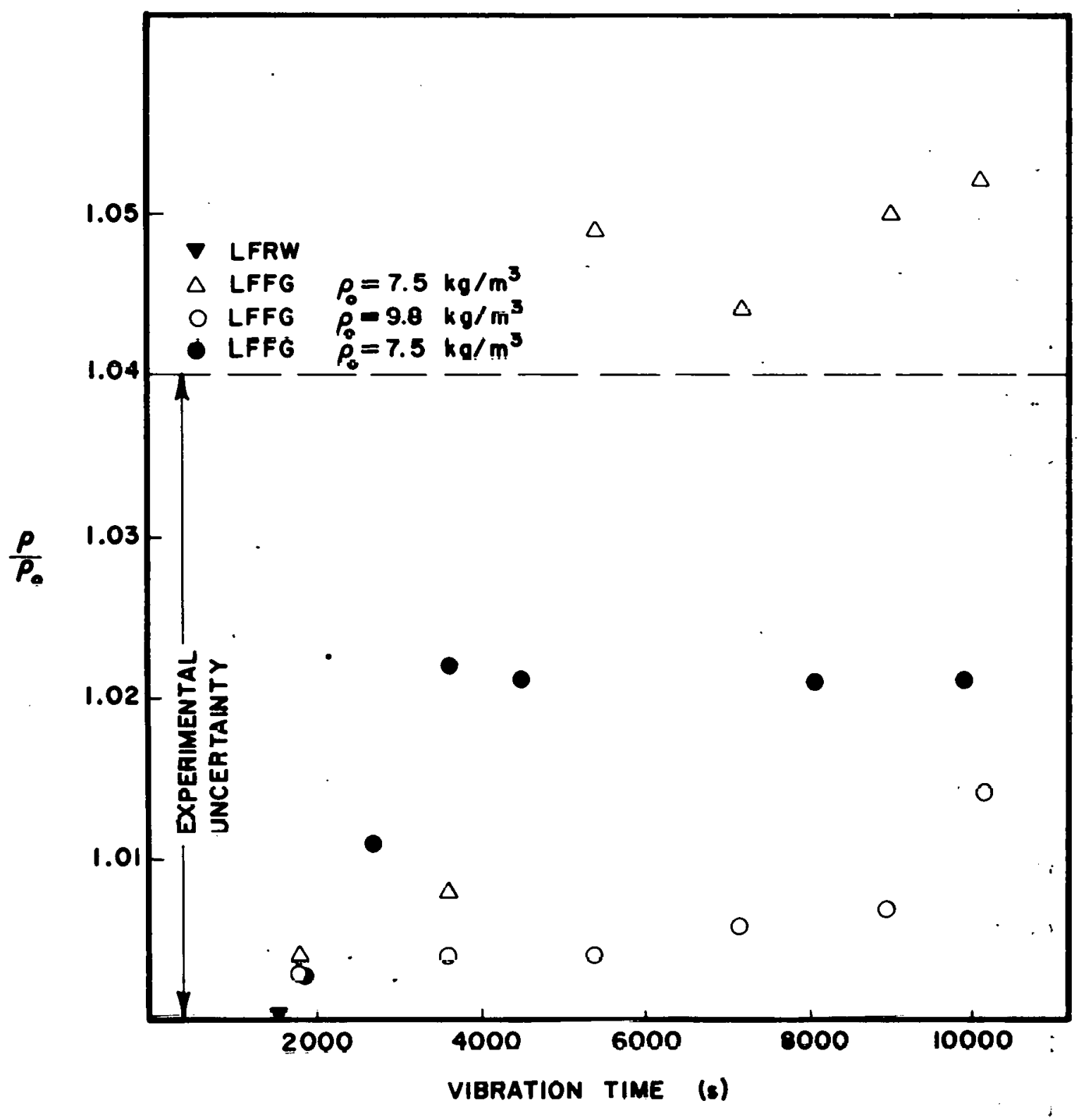

Figure 6. Sill1iug Factoro Ubtained Will The Modified Polishing Machine 
the low amplitude-low frequency vibration tests of reasonable durations do not have sufficient effect on the loose-fill material to make laboratory evaluations practical.

The $152 \mathrm{~mm}$ (6.0 inches) drop test was applied to. LFFG, LFRW, and loose-fill cellulosic insulation, LFC. Typical curves of $\rho / \rho_{0}$ versus number of drops which were obtained from a Least Squares analysis are shown in Figure 7. Equation (4) was used to obtain a mathematical representation of the experimental data. Values for the parameters $a$ and $b$ in Equation (4) are given in Table 1. Equation (4) is valid for interpolations within the data set but not extrapolations.

$$
\rho / \rho_{0}=1+a N+b \sqrt{N}
$$

where $\mathrm{N}$ is either the number of drops or the total vibration time in seconds.

The curves in Figure 7 are the result of curve fitting the data without regard to initial density. The fact that the resulting equations describe the experimental data to better than $\pm 3 \%$ supports the observation that blown density is not a strong factor within the density ranges tested. Experimental results for $\rho / \rho_{0}$ atter repealed $19 \mathrm{~mm}$ (.75 inch) drnps have been correlated using Equation (4) and are shown in Figure 8 . The parameters $a$ and $b$ for this test are given in Table 1.

The order in which the loose-fill products settle due to $19 \mathrm{~mm}$ drops is consistent with the $152 \mathrm{~mm}$ drop test data, i.e.: LFRW > LFFG > LFC. The observation that the settlement factor curves for $152 \mathrm{~mm}$ drops fall above the corresponding $19 \mathrm{~mm}$ drop curves is' consistent with the fact that the velocity on impact varies with the square root of the drop distance.

Vibration tests at $10 \mathrm{~Hz}$ and $2.54 \mathrm{~mm}$ (0.10 inch) vert1cal displacement 
ORNL-DWG $81-9450$

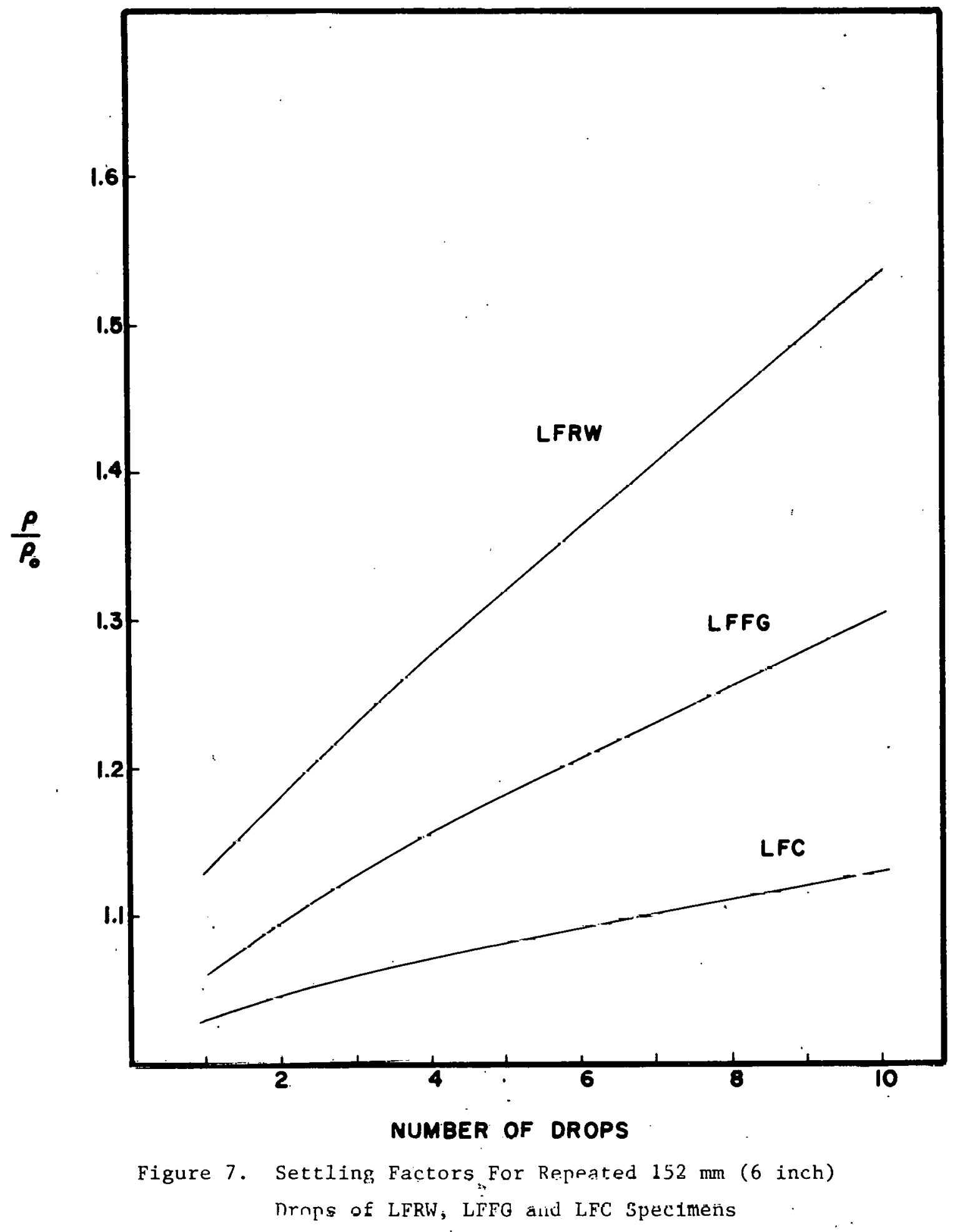


3

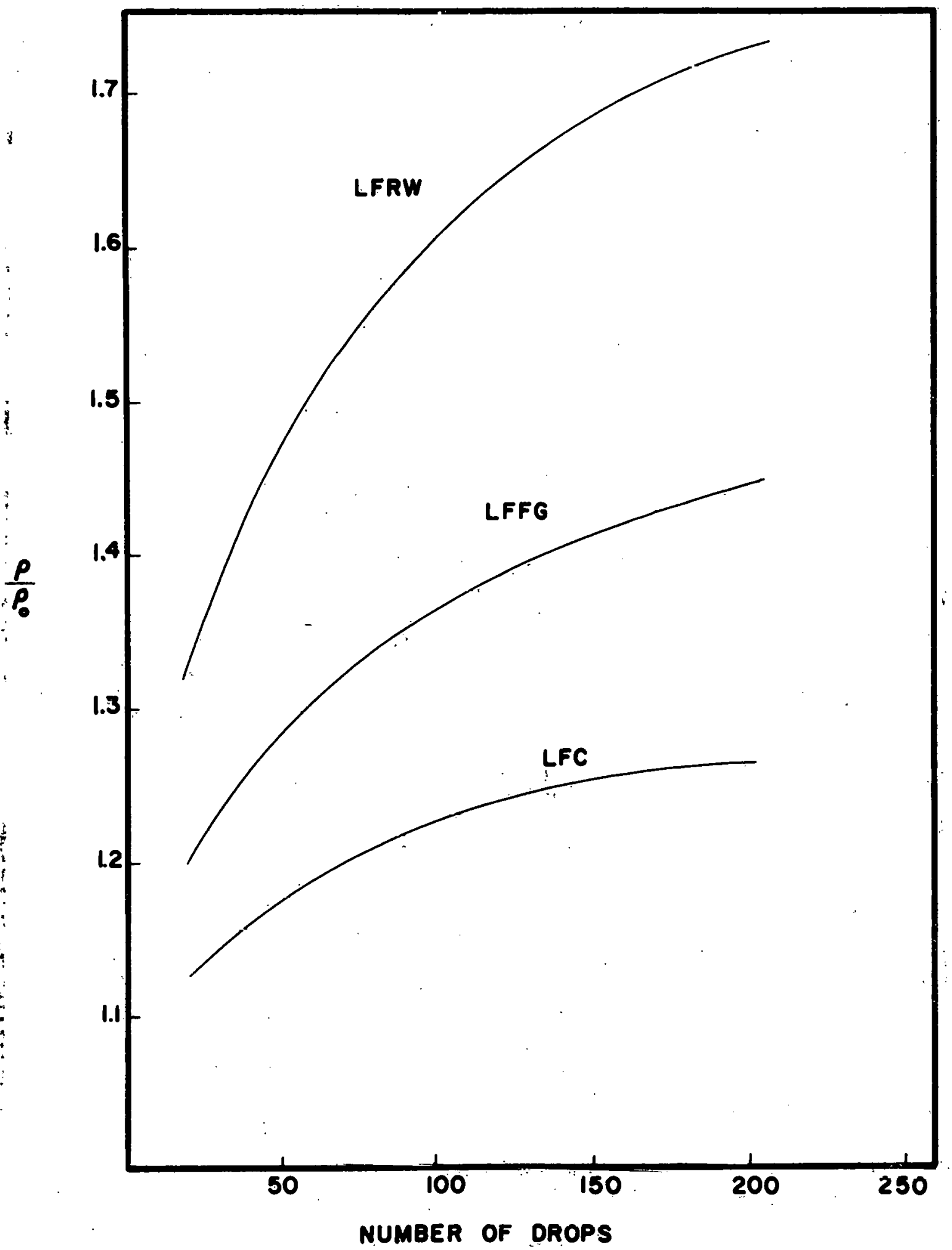

Figure 8. Settling Factors For Repeated $19 \mathrm{~mm}$ (.75 inch) Drops of LFRW, LFFG, and LFC Specimens 
TAELE 1

Valıes for $a$ and $b$. in Equation (4)

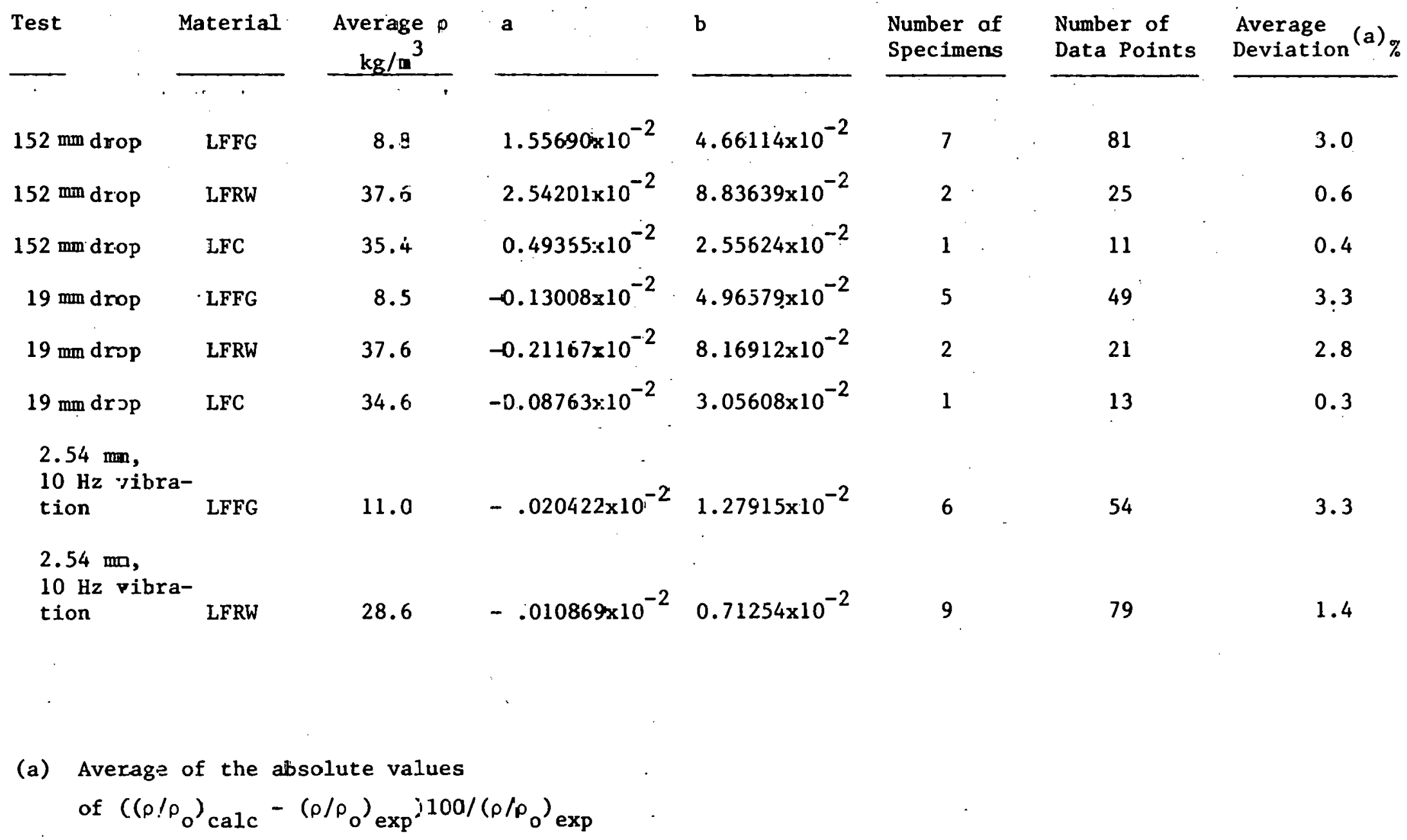


were completed for three specimens of LFC, nine LFRW specimens and six LFFG specimens using the vibration test machine. The constants $a$ and $b$ in Equation (4) were obtained for LFRW and LFFG for the entire data set. Figures 9 and 10 summarize much of the test data obtained at $10 \mathrm{~Hz}$ and $2.54 \mathrm{~mm}$.

Figure 9 gives $\rho / \rho_{0}$ as a function of $\rho_{0}$ for $1800 \mathrm{~s}$ of vibration at $10 \mathrm{~Hz}$ and $2.54 \mathrm{~mm}$. The data for each of the three insulations show the variation of settling factor observed at different blown densities with a given material. The mineral fiber insulations show a trend toward decreased settlement with increased blown density. The number of cellulose samples, three, was too small to determine a $\rho_{0}$ variation. The trend line in Figure 9 ties together the data for the three types of insulation tested and shows that settling decreases sharply with increased densities.

Average values of the settling factor for LFC, LFRW, and LFFG are shown in Figure 10 as a function of vibration time. These data which are for $10 \mathrm{~Hz}$ and $2.54 \mathrm{~mm}$ of displacement clearly show the settlement ordering among the three products, i.e., LFC < LFRW < LFFG. The curves shown in Figure 10 result from calculation of the average value of $\rho / \rho_{0}$ after four periods of vibration. There is a small difference between the curves in Figure 1 and the least square results summarized in Talle 1.

The variations of $\rho / \rho_{0}$ with frequency and displacement have also been determined for the three loose-fill products tested. Test series were completed at displacements from $1.27 \mathrm{~mm}$ (.05 inch) to $6.35 \mathrm{~mm}$ ( 0.25 inch) and from $10 \mathrm{~Hz}$ to $30 \mathrm{~Hz}$. Selected numerical results are given in Table 1 . For each of the products tested results are also given for the variation of $\rho / \rho_{\circ}$ with displacement at a fixed vibration frequency of $10 \mathrm{~Hz}$. Frequency variation results are given for a constant displacement of $3.81 \mathrm{~mm}$ (.15 inches). The variations of $\rho / \rho_{0}$ with displacement are shown in Figure lla for LFFG, Figure $11 \mathrm{~b}$ for LFRW, and Figure 1.1c for LFC. In each case data for 
ORNL-DWG $81-9446$

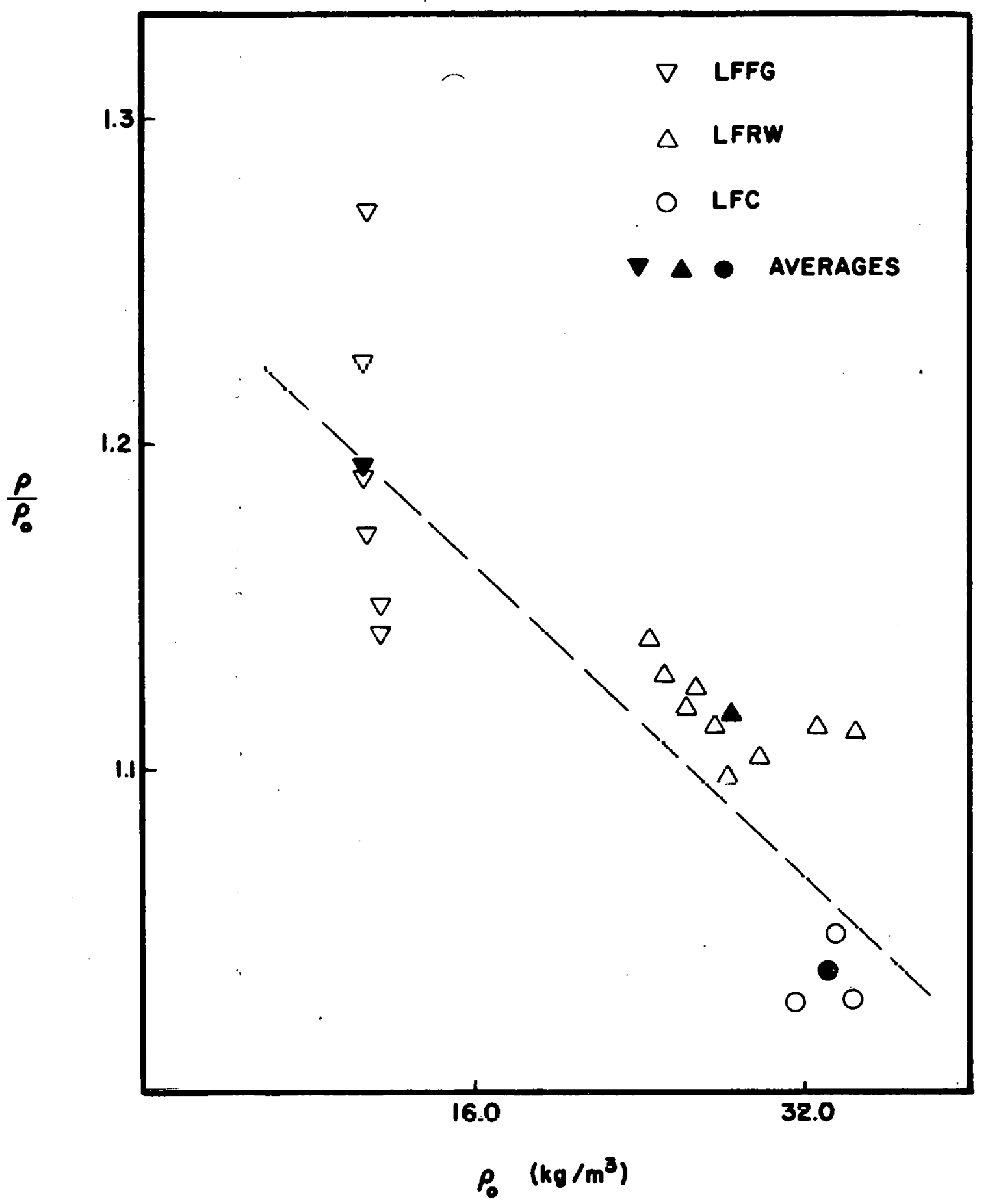

Figure 9. Settling Factors as a Function of Blown Denoity fui Luuse-F111 Insulations Vibrated for $1800 \mathrm{~s}$ at $10 \mathrm{~Hz}$ and $2.54 \mathrm{~mm}$ (.1 inch) of Displacement 
ORNL-DWG $81-9451$

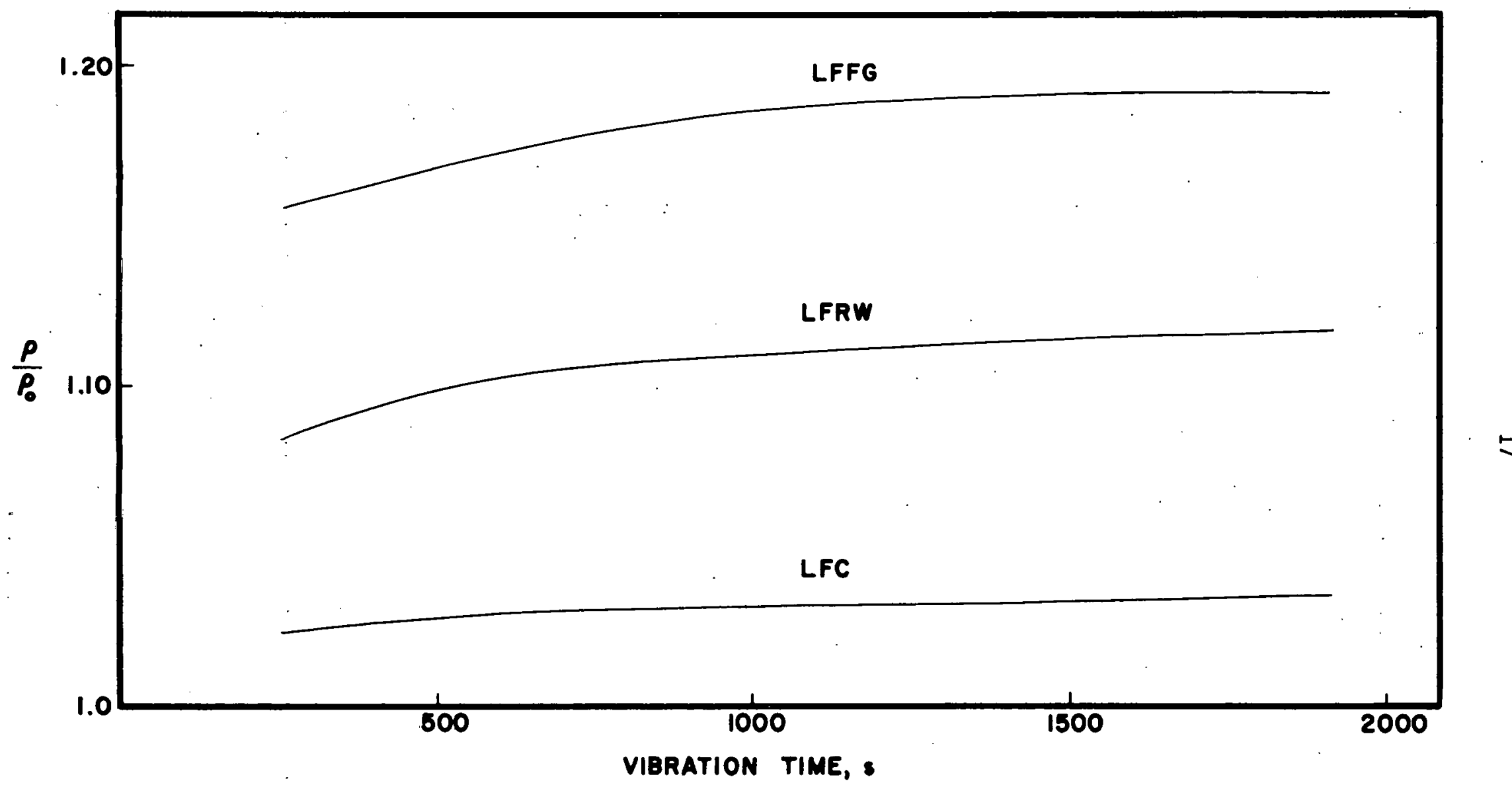

Figure 10. Settling Factors as a Function of Time for Loose-Fill Insulations Vibrated at $10 \mathrm{~Hz}$ and $2.54 \mathrm{~mm}$ (.1 inch) of Displacement 
ORNL-DWG $81-9445$

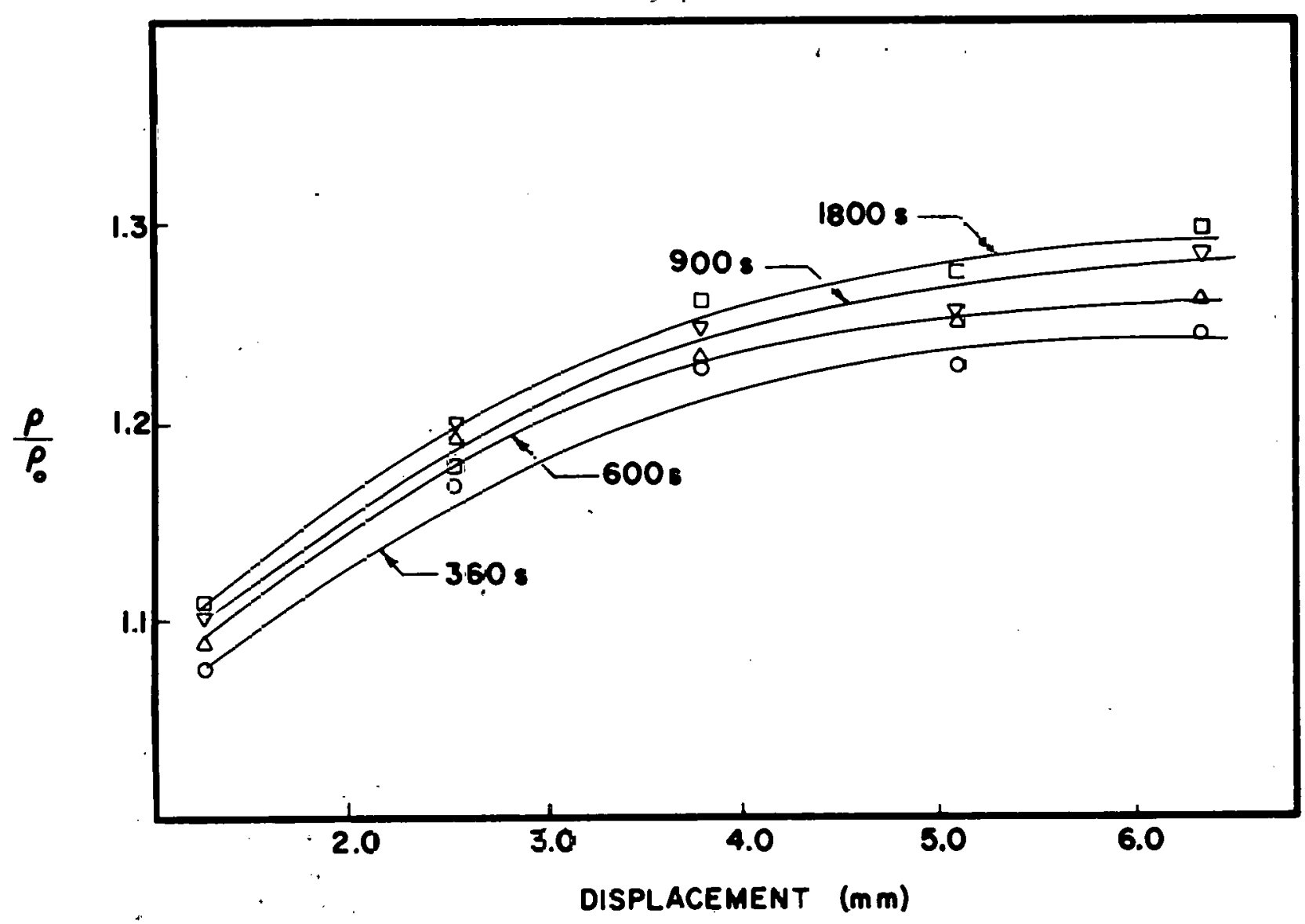

Figure 1la. Settling Factors for LFFG Resulting from 10 Jz Jibrations 
ORNL-DWG $81-9444$

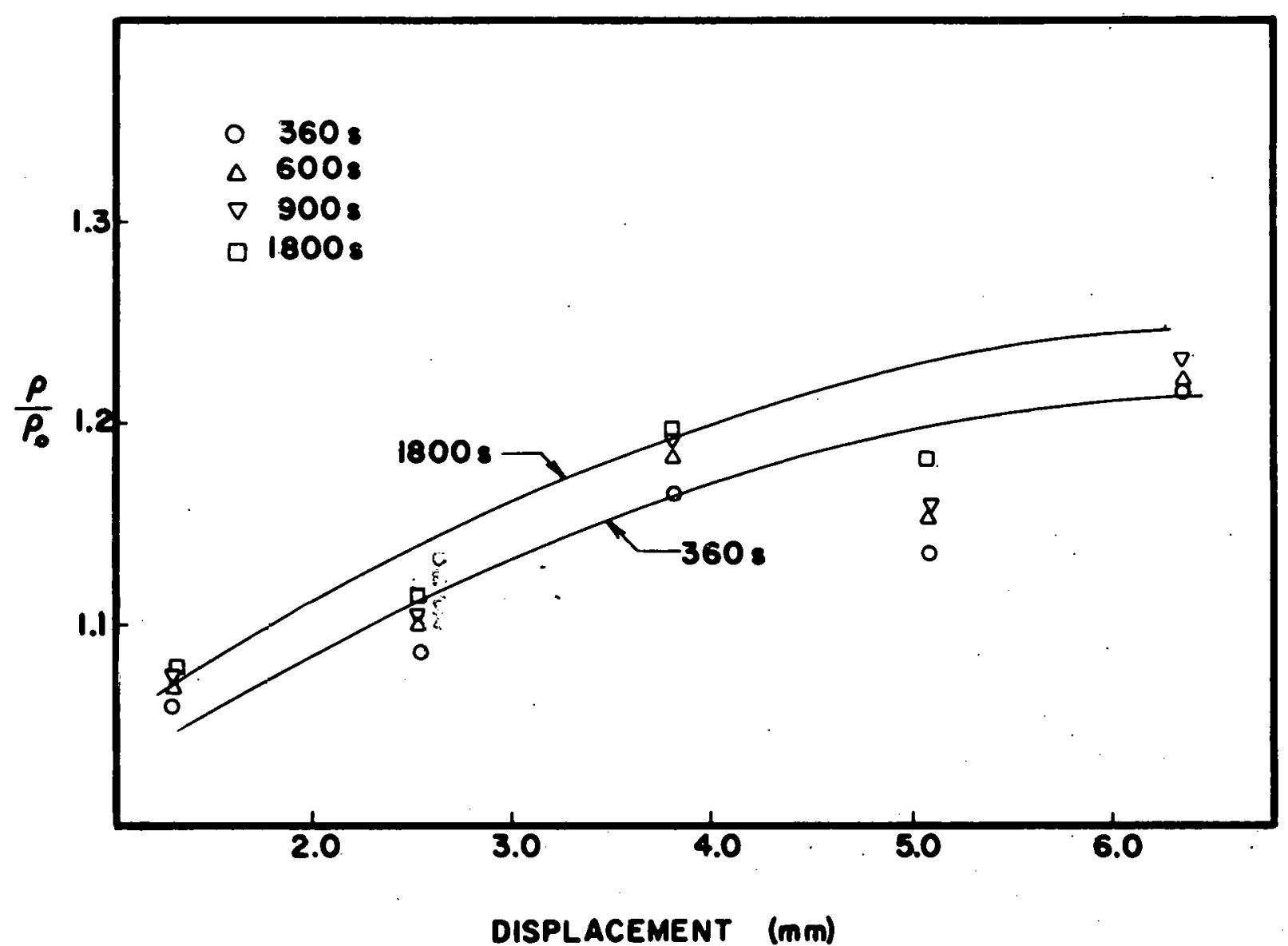

Figare 1lb. Settling Factors for LFRW Resulting from $10 \mathrm{~Hz}$ Vibrations 
OFFL-DWG 81-9443

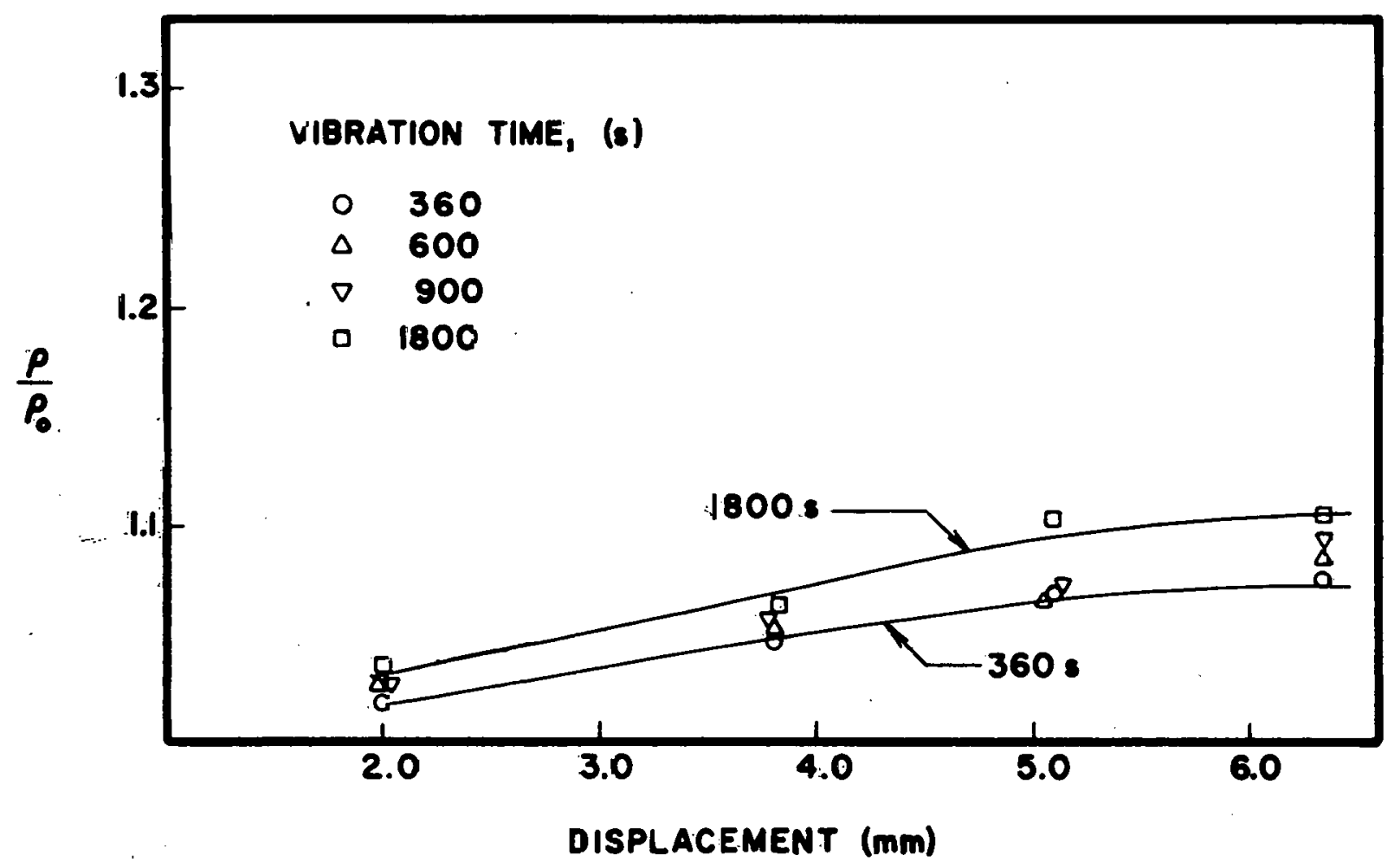

ก

Figure 11:. Sectling Factors for LFC Resulting from

$10 \mathrm{~Hz}$ Vibrations 
ORNL-DWG 81-94.42

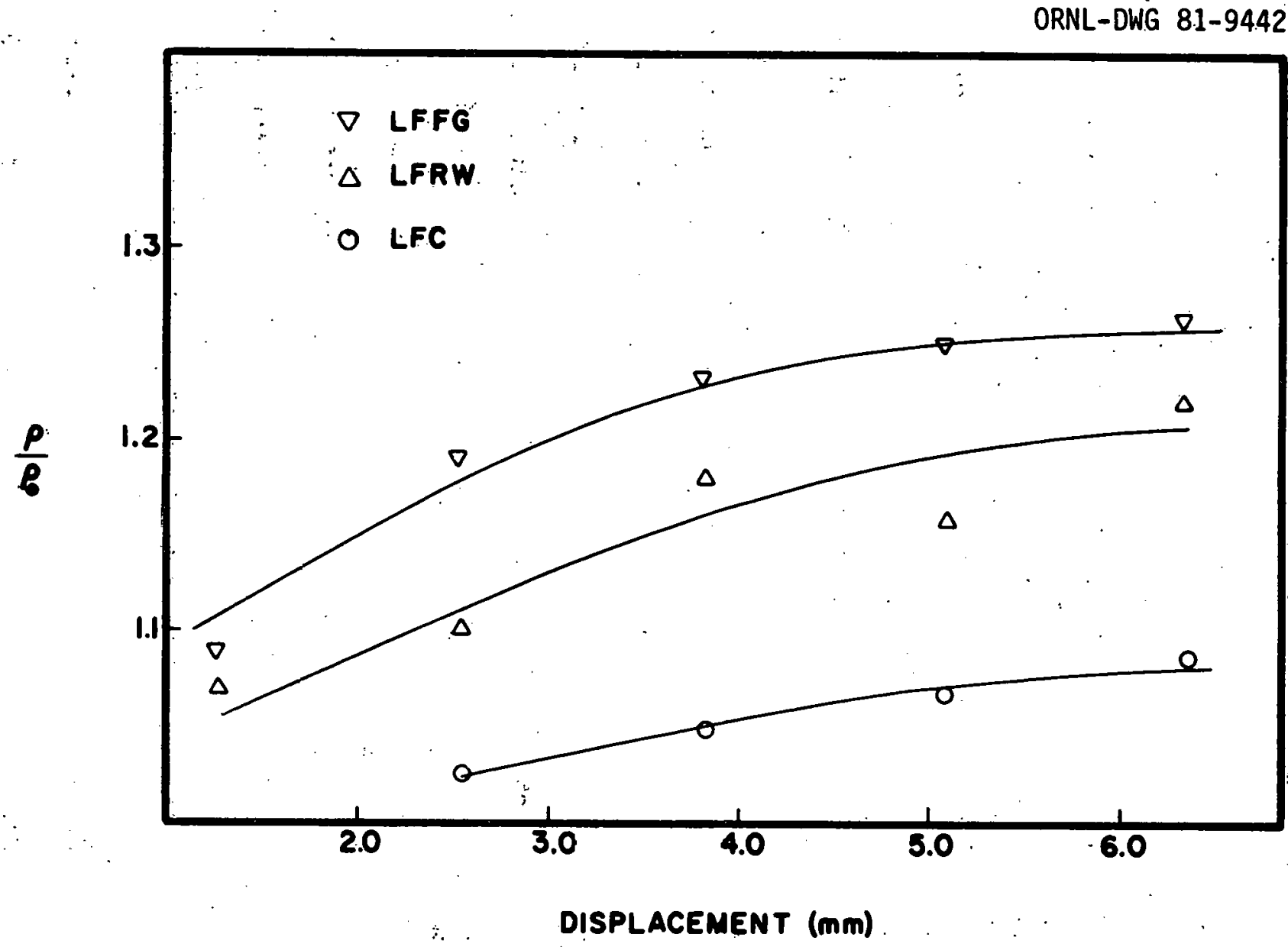

Figure 12. Settling Factors for Loose-Fill Insulations as a Function of Vibration Displacement for 600 Seconds at $10 \mathrm{~Hz}$ 
ORNL-DWG 81-9441

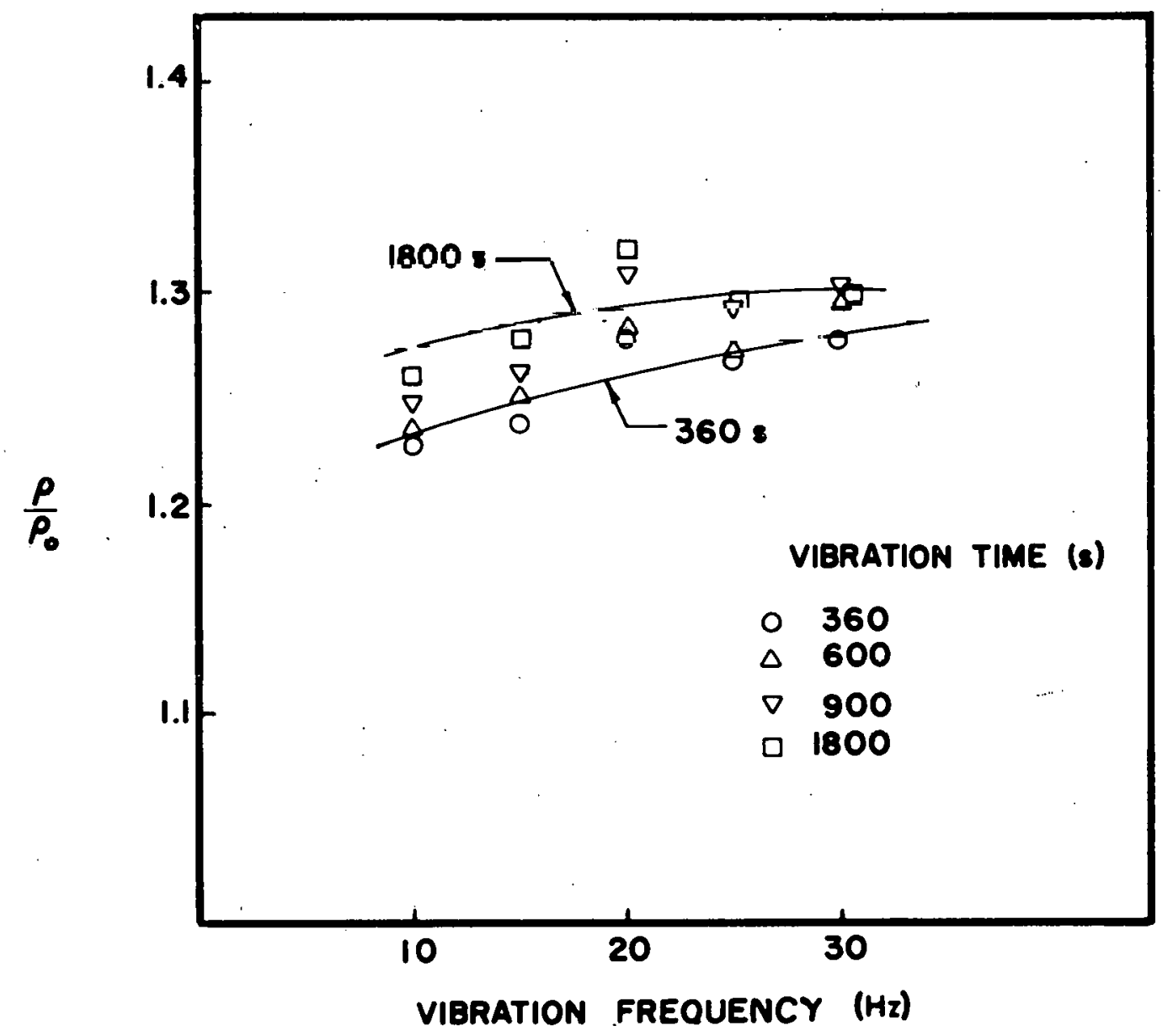

F1gure 13a. Settling Factors as a Function of Vibration Frequency fur LFFG Tested at $3.81 \mathrm{~mm}$ (.15 inch) Displacement 


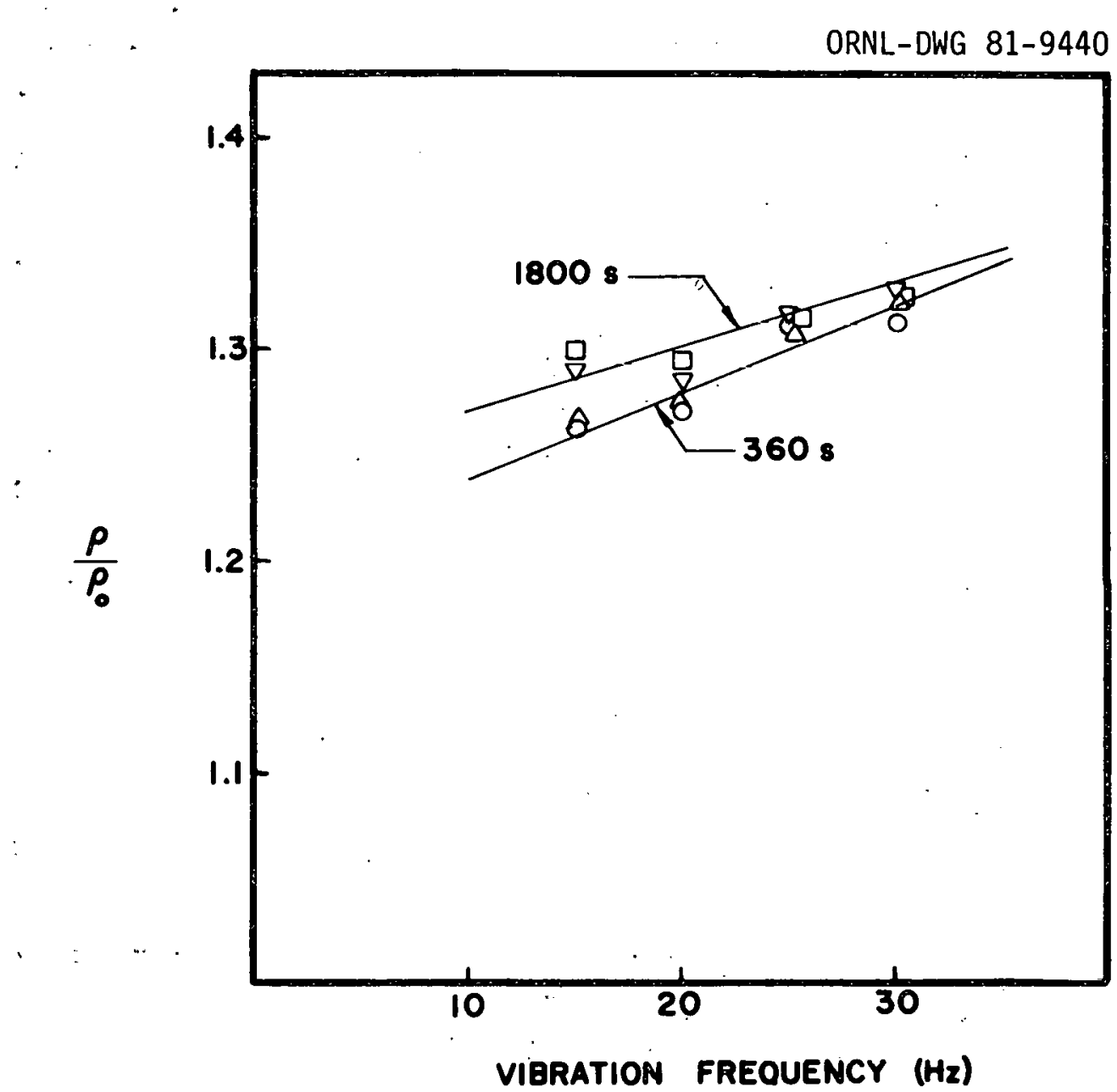

Figure 13b. Settling Factors as a Function of Vibration Frequency for LFRW Tested at $3.81 \mathrm{~mm}$ (.15 inch) Displacement 


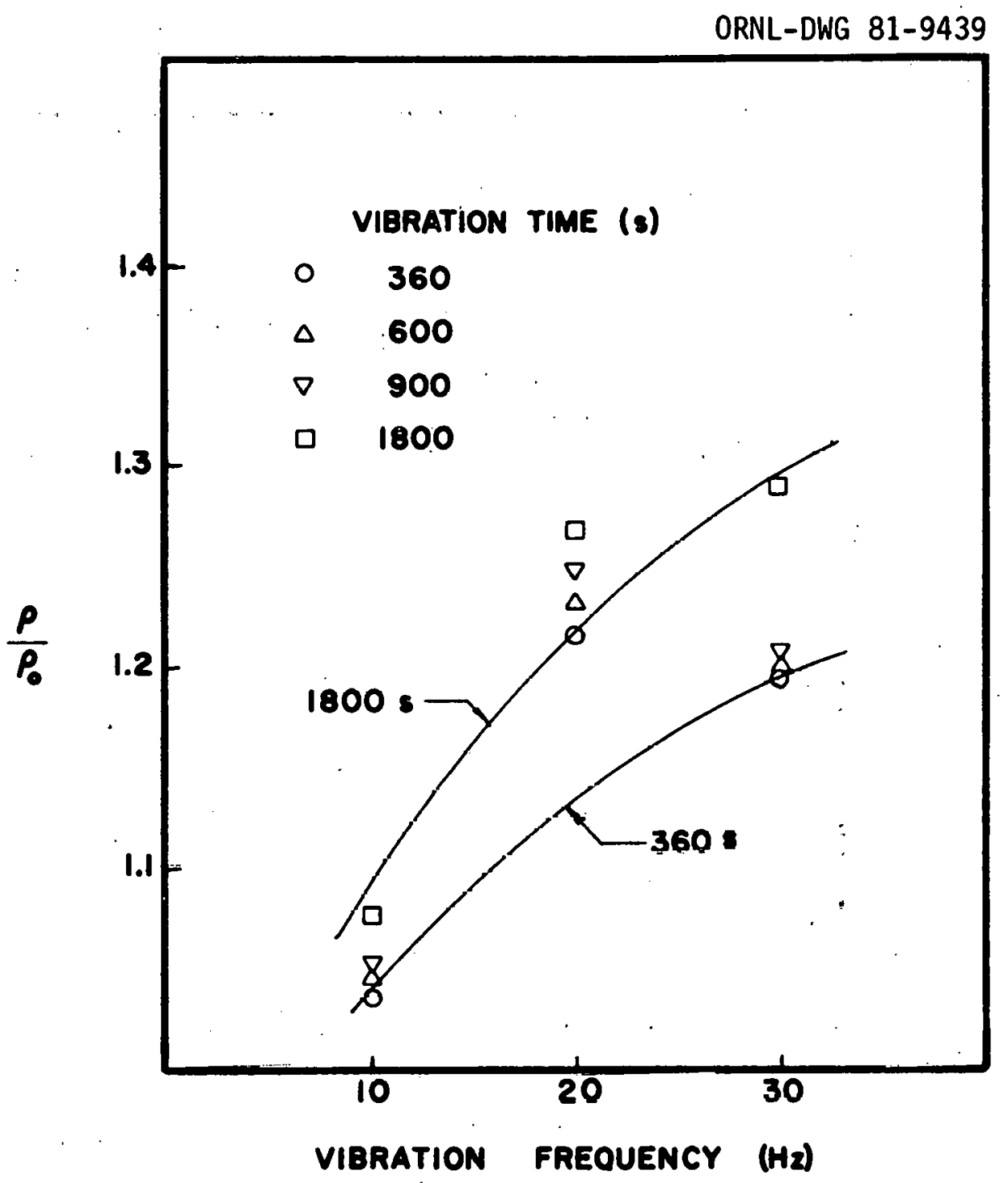

Figure 13c. Settling Factors as a Function of Vibration Frequency for LFC Teoted at 3.81 um (.15 inch) Displacement 


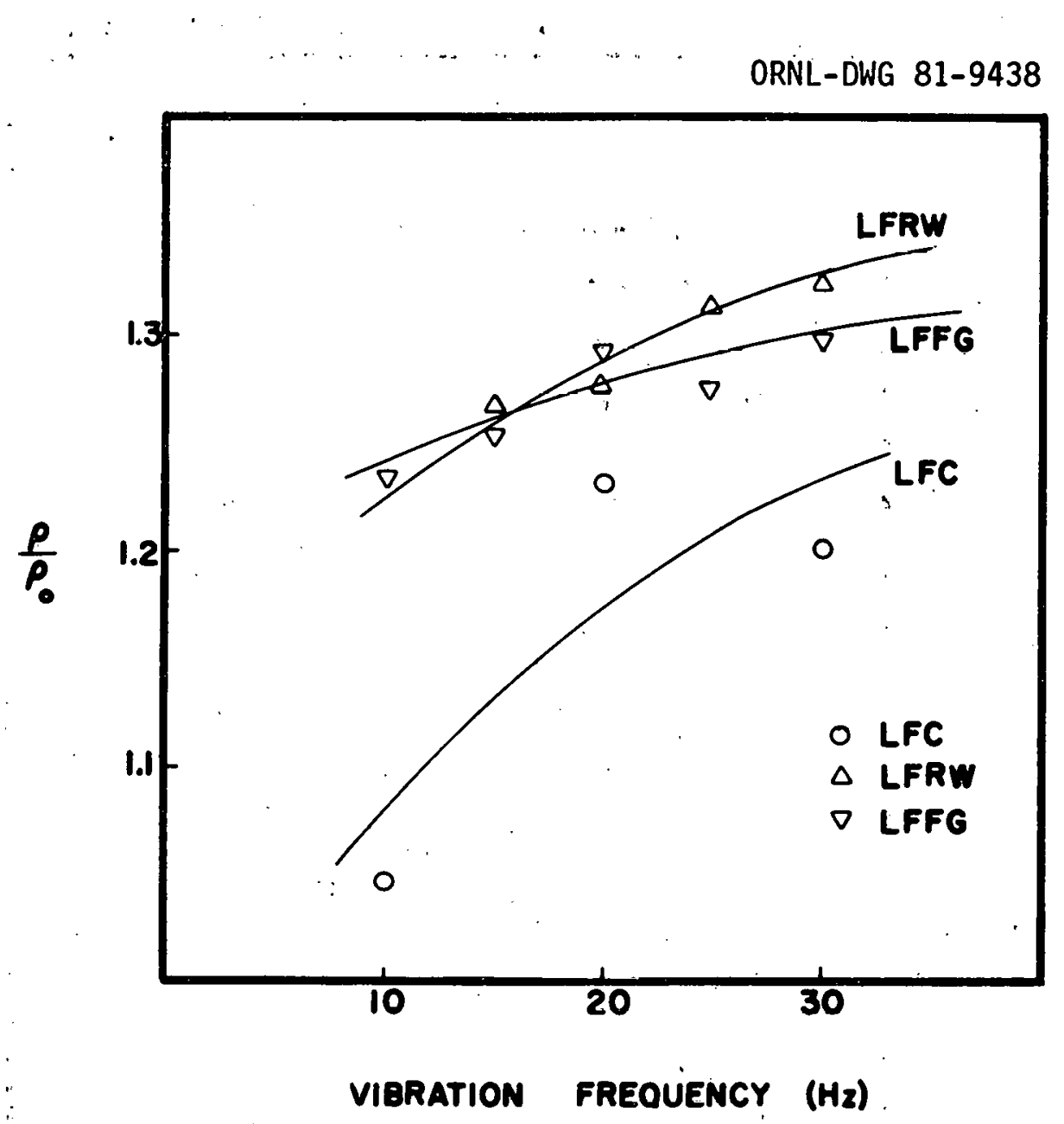

Figure 14. "A Comparison of Settling Factors for LFFG, LFRW, and LFC for $600 \mathrm{~s}$ Tests at $3.81 \mathrm{~mm}$ (.15 inch) Displacement 
four vibration times and a fixed frequency of $10 \mathrm{~Hz}$ show that a large fraction of the settling takes place during the early increments of vibration. The data also exhibit a "leveling-off" at the upper end of the displacement scale. A single graphical comparison of the three products appears in Figure 12. Figure 12 demonstrates that the settlement factor decreases with increase in product density.

Variation of $\rho / \rho_{0}$ with vibration frequency at a fixed displacement of $3.81 \mathrm{~mm}$ ( 0.15 inches) is given in Figure 13a for LFFG, Figure 13b for LFRW and Figure $13 c$ for LFC. In each case the $\rho / \rho_{0}$ values generally increase with frequency. There are two cases where the $\rho / \rho_{0}$ values versus frequency appear to be out of order. The scatter is postulated to be the result of a limited number of measurements at the frequencies in question. No adjustments have been made for variations in blown density.

The 600 second data shown in Figure 13a-c are compared in Figure 14. In this case the results for LFRW and LFFG are superimposed while the LFC tests show smaller $\rho / \rho_{u}$ values and an apparent saturation effect between 10 and $20 \mathrm{~Hz}$.

\section{Conclusions}

The following conclusions are based on the laboratory data collected in this study. Quantitative results wust be read with the understanding that the sample of products tested was not nationwide but rather was restricted to insulation materials purchased from local outlets.

The three 1oose-f11l insulations; LFFG, LFRW and LFC; show settling as a result of laboratory vibration or drop tests. Repeated $19 \mathrm{~mm}$ drops resulted in maximum. $\rho / \rho_{0}$ values of about 1.75 for LFFG, 1.45 for LFRW and 1.27 for LFC. 
The settling factor, $\rho / \rho_{0}$, for a given product type is not strongly dependent on initial density within the range of densities tested.

The settling factors due to $2.54 \mathrm{~mm} 10 \mathrm{~Hz}$ vibrations showed a dramatic decrease with initial density increase when data from all products are considered together. The magnitudes for $\rho / \rho_{0}$ are ordered LFFG > LFRW > LFC for this test.

- Settling factors due to vibration tests increase with the duration of the test. Increases of $\rho / \rho_{0}$ after $1800 \mathrm{~s}$ of testing, however, are negligible.

- Relatively brief, $10,000-20,000 \mathrm{~s}$, vibration periods at $0.1 \mathrm{~mm}$ displacement and $60 \mathrm{~Hz}$ showed density increases equal to or less than the measurement uncertainty."

Settling factors increase with vibration frequency or dieplacement in the ranges tested but appear to level-off between 4 and $5 \mathrm{~mm}$ of displacement at $10 \mathrm{~Hz}$ for the mineral fiber products.

The results of this study show that all three of the loose-fill insulations tceted settle as a resi1t. nf impacts or vibrations. It is recommended that the degree of settling for the three materials be determined by one test method. Determinations of design density using data from a precision vibration testing machine at specified test conditions of displacement, frequency and duration represents the best defined test and 
could be combined with an environmental test. Specification of the vibration test conditions should be consistent with observations of installed loose-fill products. 


\section{$\underline{\text { References }}$}

1. MEDEARIS, KENNETH, "Blasting Vibration Damage Criteria for Low-Rise Structures", Sound and Vibration (November, 1978) pages 23-27.

2. - - - , "Ceiling Vibrations in a Typical House--A Pilot Study", National Association of Home Builders Research Foundation, Inc., CR-7097A (December, 1978).

3. SMTTH, CY and T. F. SCANLAN, unpublished report, Oak Ridge National Laboratory, Oak Ridge, Tennessee (September, 1980).

4. Universal Automatic Insulating Machine Model SC-47WR Ultra-Matic Mark II Custom manufactured by Unisul, Inc., Winter Haven, Florida 33880.

5. Cadillac Hand Held Blower manufactured by Clements Manufacturing Company, Chlcago, Illinois.

6. Syntron Lapping Polishing Machine Type LPOID manufactured by FMC/Syntron, Home City, Pennsylvania

7. SHIRTLIFFE, C. J. and M. BOMBERG, "Blown Cellulose Fiber Thermal Insulations," Division of Building Research, National Research Council of Canada paper No. 820. American Society for Testing and Materials Special Technical Publication No. 660, Part 1. 82-103 (December, 1978). 
ORNL/Sub $-7715 / 3$

\section{INTERNAL DISTRIBUTION}

1-2. Central Research Library

3. Document Reference Section

4-5. Laboratory Records

6. Laboratory Records, ORNL RC

7. ORNL Patent Office

8. R. S. Carlsmith

9. P. T. Carlson

10. K. W. Childs

11. G. E. Courville

12. F. A. Creswick

13. R. G. Donnelly

14. C. S. Dudney

15. W. Fulkerson

16. M. Guthrie

17. W. W. Harris

18. D. R. Johnison
19-43. T. S. Lundy

44. M. C. Matthews

45. J. W. Michel

46. R. E. Minturn

47. E. L. Preston

48. J. N. Robinson

49. M. W. Rosenthal

50. T. F. Scanlan

51. A. C. Schaffhauser

52. J. 0. Steigler

53. D. B. Trauger

54. P. J. Walsh

55. J. R. Weir, Jr.

56. R. L. Wendt

57-66: D. W. Yarbrough

EXTERNAL DISTRIBUTION

67. P. R. Achenbach, 1322 Kurtz Road, McLean, VA 22101

68. R. W. Anderson, 7090 Tecumseh Lane, Chanhassen, MN 55317

69. E. L. Bales, DOE/BCS, Washington, DC 20585

70. J. Barnhart, TIMA, Mt. Kisko, NY 10549

71. R. W. Beausoliel, NBS-G, Washington, DC 20234

72. M. Be11, NAHB, 15th and M Streets, NW, Washington, DC 20005

73. A. L. Berlad, State University. of New York, Stony Brook, NY

74. J. J. Boul in, DOE/BCS, Washington, DC 20585

75. W. Brenner, NIBS, Washington, DC 20005

76. J. Cable, DOE/BCS, Washington, DC 20585

77. S. H. Cady, Mineral Insulation Manufacturers Assn., Summit, NJ

78. W. Carroll, Lawrence Berkeley Laboratory, Berkeley, CA 94720

79. H. I. Cohen, Consumer Product Safety Commission, Washington, DC

80. R. W. Cole, New Mexico Energy Institute, Albuquerque, NM

81. S. Davis, National Bureau of Standards, Washington, OC 20234

82. R. S. Dougall, University of Pittsburgh, Pittsburgh, PA

83. W. P. Ellis, H. B. Fuller Co., Spring House, PA

84. A. E. Fiorato, Portland Cement Assn., Skokie, IL

85. C. W. Frank, University of Iowa, Oakdale, IA

86-95. E. C. Freeman, DOE/BCS, Washington, DC 20585

96. B. F. Gilmartin, Owens-Corning Fiberglas, Washington, DC

97. L.:R. Gi icksman, Massachusetts Institute of Technology, Cambridge, MA

98. D. Goldenburg, TRW, Inc., Oak Ridge, TN 37830

99. F. A. Govan, Brushwood Road, Stamford, CT 
100. A. Greenberg, Geo-Energy Ltd., Port Jervis, NY

101. R. F. Hemphi11, TVA, Chattanooga, TN

102. C. Hollowe 11, Lawrence Berkeley Laboratory, Berkeley, CA

103. J. G. Hust, National Bureau of Standards, Boulder, CO

104. R. R. Jones, National Bureau of Standards, Washington, DC

105. W. Kleinfelder, Underwriters Laboratories, Inc., Northbrook, IL

106. W. M. Kroner, Rensselaer Polytechnic Institute, Troy, NY

107. D. Lamb, TVA, Chattanooga, TN

108. S. Launey, DOE/BCS, Washington, DC 20585

109. E. Lisee, ACEC Research \& Management Foundation, Washington, DC

110. K. R. Long, University of Iowa, Oakdale, IA

111. E. L. Marvin, Headquarters, Department of Army, Washington, DC

112. K. Mentzer, MIMA, 382 Springfield Avenue, Summit, NJ

113. J. T. Miller, GSA, Washington, DC

114. W. V. Miller, Clvil Engineering l.ahoralory, Porl. Hueneme, CA

115. J. P. Millihone, DOE/BCS, Washington, DC 20585

116. D. E. Morgenroth, Owens-Corning Fiberglas, Toledo, $\mathrm{OH}$

117. W. R. Newton, TVA, Chattanooga, TN

118. E. Palmer, Assn: of Collegiate Schools of Architecture, Washington, DC

119. R. L. Parks, Underwriters Laboratories, Inc., Northbrook, IL

120. F. J. Powel1, National Bureau of Standards, Washington, DC

121. J. M. Roehm, PO Box 887, Virginia Beach, VA

122. H. D. Ross, DOE/BCS, Washington, DC 20585

123. M. Savitz, DOE, Washington, DC 20585

124. E. Schaffer, Forest Products Laboratory, Madison, WI

125. S. Selkowitz, Lawrence Berkeley Laboratory, Berkeley, CA

126. M. Shahin, CERL, Champaign, IL

127. M. Sherman, Jim Walter Research Corporation, St. Petersburg,FL

128. C. J. Shirtliffe, National Research Council, Ottawa, Canada

129. T. T. Shishman, Bickle, CRS Group, Inc., Albuquerque, NM

130. M. K. Snyder, Butler Mfrj., Co. Researrh Center, Grandview, MO

131. R. Sonderegger, Lawrence Berkeley Laboratory, Berkeley, CA

132. E. Stamper, New Jersey Institute of Technology, Newark, NJ

133. J. R. Tanck, DOE/BCS, Washington, DC 20585

134. G. J. Teitsma, Dow Chemical Company, Granville, $\mathrm{OH}$

135. J. Thompson, State of Oregon DOE, Salem, OR

136. C. L. Tien, University of California, Berkeley, CA

137. G. A. Tsongas, Portland State University, Portland, OR

138. R. P. Tye, Fiber Materials, Inc., Biddeford, ME

139. C. R. Vander Linden, Johns-Manville Sales Corp., Denver, CO

140. J. D. Verschoor, Johns-Manville R\&D Center, Denver, CO

141. S. S. Waddle, DOE/ORO, Oak Ridge, TN 37830

142. R. Weil, Stevens Institute of Technology, Hoboken, NJ

143. J. T. Wood, DCS Corporation, Arlington, VA

144-221. Buildings Division Distribution List

222: Assistant Manager for Energy Research and Development, ORO, Oak Ridge, TN

223-249. Technical Information Center, PO Box 62, Oak Ridge, TN 37830 